\title{
Unveiling novel genes upregulated by both rhBMP2 and rhBMP7 during early osteoblastic transdifferentiation of $\mathrm{C} 2 \mathrm{C} 12$ cells
}

\author{
Juan C Bustos-Valenzuela', Andre Fujita², Erik Halcsik', Jose M Granjeiro ${ }^{3}$ and Mari C Sogayar ${ }^{1 *}$
}

\begin{abstract}
Findings: We set out to analyse the gene expression profile of pre-osteoblastic $\mathrm{C} 2 \mathrm{C} 12$ cells during osteodifferentiation induced by both rhBMP2 and rhBMP7 using DNA microarrays. Induced and repressed genes were intercepted, resulting in 1,318 induced genes and 704 repressed genes by both rhBMP2 and rhBMP7. We selected and validated, by RT-qPCR, 24 genes which were upregulated by rhBMP2 and rhBMP7; of these, 13 are related to transcription (Runx2, DIx1, D/x2, Dlx5, Id1, Id2, Id3, Fkhr1, Osx, Hoxc8, Glis1, Glis3 and (fdp1), four are associated with cell signalling pathways (Lrp6, Dvl1, Ecsit and $P K C \delta)$ and seven are associated with the extracellular matrix (Ltbp2, Grn, Postn, Plod1, BMP1, Htra1 and IGFBP-rP10). The novel identified genes include: Hoxc8, Glis1, Glis3, Ecsit, PKC $\delta$, LrP6, Dvl1, Grn, BMP1, Ltbp2, Plod1, Htra1 and IGFBP-rP10.

Background: BMPs (bone morphogenetic proteins) are members of the TGF $\beta$ (transforming growth factor- $\beta$ ) super-family of proteins, which regulate growth and differentiation of different cell types in various tissues, and play a critical role in the differentiation of mesenchymal cells into osteoblasts. In particular, rhBMP2 and rhBMP7 promote osteoinduction in vitro and in vivo, and both proteins are therapeutically applied in orthopaedics and dentistry.

Conclusion: Using DNA microarrays and RT-qPCR, we identified both previously known and novel genes which are upregulated by rhBMP2 and rhBMP7 during the onset of osteoblastic transdifferentiation of pre-myoblastic C2C12 cells. Subsequent studies of these genes in C2C12 and mesenchymal or pre-osteoblastic cells should reveal more details about their role during this type of cellular differentiation induced by BMP2 or BMP7. These studies are relevant to better understanding the molecular mechanisms underlying osteoblastic differentiation and bone repair.
\end{abstract}

\section{Background}

Bone formation and fracture repair depends on the expression and action of the bone morphogenetic proteins (BMPs), which are members of the transforming growth factor beta (TGF-beta) superfamily of dimeric, disulphide-linked growth factors, comprising more than 15 related proteins. In addition to a crucial role in osteogenesis, BMPs display a myriad of roles in cell proliferation, differentiation, migration and apoptosis, in different cell types [1]. Their role is essential at early

\footnotetext{
* Correspondence: mcsoga@iq.usp.br

${ }^{1}$ Chemistry Institute, Department of Biochemistry, Cell and Molecular Therapy Centre (NUCEL), University of São Paulo, Avenida Prof. Lineu Prestes, 748 Bloco 9S, São Paulo, SP 05508-000, Brazil

Full list of author information is available at the end of the article
}

phases of development and organogenesis, such as axial embryo determination [2], as well as in limb, eye and kidney development, such that ablation of these genes results in death at very early stages of development, as observed in knock-out mice [3]. In humans, recombinant BMP2 and BMP7 have gained attention in bone repair and in non-union spinal fractures due to their capacity to stimulate the differentiation of mesenchymal stem cells from the periosteum near the lesion site after migration and proliferation induced by IL-1, IL-6, and TNF- $\alpha$ [4]. This feature was first observed in the 1960s through the ectopic bone formation activity induced by bone extracts [5]. However, since only a few clinical trials concerning the use of these proteins are available, questions about the amount of BMPs required for

C Biomed Central

(c) 2011 Sogayar et al; licensee BioMed Central Ltd. This is an open access article distributed under the terms of the Creative Commons Attribution License (http://creativecommons.org/licenses/by/2.0), which permits unrestricted use, distribution, and reproduction in any medium, provided the original work is properly cited. 
complete bone regeneration and the extent of side effects caused by their application remains unclear.

BMPs can activate osteoblastic differentiation by binding to two different surface receptor classes on the cells, namely: type I receptors or activin receptor-like kinases (Alk 2, 3 and 6) and type II receptors (BMPR2 and activin A receptors type IIA and IIB), which are constitutively active, and transfer a phosphoryl group to serine and threonine residues in type I receptors upon ligand binding. Nevertheless, this binding is specific for each type of BMP, since BMP2 displays higher affinity for the Alk2 and Alk3 receptors, whereas BMP7 has more affinity for Alk2 receptors [6]. In addition, the downstream signalling pathway depends on how these receptors are disposed. When the receptors are already dimerised (PFC; pre-formed complex) prior to BMP binding, the Smad downstream pathway is activated through the Smad proteins 1, 5 and 8, which activate Runx2, Dlx 5 and Osterix (Osx). In the BMP-induced signalling complex (BISC), BMP binding leads to receptor dimerisation; the caveosome-directed pathway leads to MAPK activation, which leads to an induction of RunX2 expression and phosphorylation, thus determining osteoblastic differentiation [1]. Moreover, in vitro studies have shown activation of the Osx proteins in Smad knockdown cell lines, indicating independent MAPK-activated osteoblastic differentiation. On the other hand, ERK1/2 has been found to inhibit Smad and halt bone formation [7]. These findings suggest that osteoblastic differentiation is a time-dependent process, involving the activation and inhibition of different substrates and expression of different types of genes whose nature remains to be elucidated. To investigate the transcriptional events which are independently regulated by BMP2 and BMP7, we used a gene expression microarray platform containing DNA sequences corresponding to 36,000 genes and RT-qPCR to examine the expression of early genes during osteogenic transdifferentiation in pre-myoblastic $\mathrm{C} 2 \mathrm{C} 12$ cells, upon induction by rhBMP2 or rhBMP7. This effort resulted in the assessment of both previously known and novel genes which are commonly activated by both rhBMPs.

\section{Material and methods Cell Culture}

The mouse pre-myoblastic and pre-osteoblastic $\mathrm{C} 2 \mathrm{C} 12$ cell line was obtained from the American Type Culture Collection. These cells were maintained in DMEM (Gibco BRL, Gaithersburg, MD, USA) containing 10\% FBS $\left(\mathrm{HyClone}^{\circledR}\right)$ and antibiotics $(100 \mathrm{U} / \mathrm{ml}$ of penicillin$\mathrm{G}$ and $100 \mathrm{mg} / \mathrm{ml}$ of streptomycin, $\mathrm{GIBCO}$ ) at $37^{\circ} \mathrm{C}$ in a humidified atmosphere of $2.5 \% \mathrm{CO}_{2}$ in air. For differentiation experiments, cells were seeded at a density of 2 $\times 10^{4}$ cells $/ \mathrm{cm}^{2}$ and grown for $24 \mathrm{~h}$. Subsequently, the medium was replaced by DMEM containing $5 \% \mathrm{FBS}$ in the presence or absence of $200 \mathrm{ng} / \mathrm{ml} \mathrm{rhBMP} 2$ or 200 ng/ml rhBMP7 (R\&D Systems Inc., Minneapolis, MN). The activity of rhBMP2 and rhBMP7 was determined by the alkaline phosphatase activity assay in $\mathrm{C} 2 \mathrm{C} 12$ cells.

\section{RNA isolation and DNA microarray hybridisation}

C2C12 cultures were collected after $0,4,8,12$ and 24h of treatment with rhBMP2 or rhBMP7 for extraction of total RNA using the RNeasy kit (Qiagen, Hilden, Germany). Each cRNA was prepared as recommended in the Amersham CodelinkTM iExpress Assay Reagent Kit manual. Briefly, the samples containing $1.5 \mu \mathrm{g}$ RNA of each culture treated for $12 \mathrm{~h}$ with each rhBMP ( 2 and 7) were mixed with $7.5 \mathrm{ml}$ of bacterial mRNAs $(10 \mathrm{pg} /$ $\mu \mathrm{l})$ and $1 \mu \mathrm{l}$ of oligo dT to a final volume of $12 \mu \mathrm{l}$. Each reaction was incubated at $70^{\circ} \mathrm{C}$ for $10 \mathrm{~min}$ and kept on ice for $3 \mathrm{~min}$. Subsequently, $2 \mu \mathrm{l}$ of $10 \mathrm{X}$ First Strand Buffer, $4 \mu \mathrm{l}$ of $5 \mathrm{mM}$ dNTPs, $1 \mu \mathrm{l}$ of RNase inhibitor and $1 \mu \mathrm{l}$ of ArrayScript were added to each tube, to a final volume of $20 \mu \mathrm{l}$. Each reaction was incubated at $42^{\circ} \mathrm{C}$ for $2 \mathrm{~h}$. After this period, each tube was placed on ice and $63 \mu \mathrm{l}$ of water, $10 \mu \mathrm{l}$ of $10 \mathrm{X}$ second strand buffer, $4 \mu \mathrm{l}$ of $5 \mathrm{mM}$ dNTPs, $2 \mu \mathrm{l}$ of DNA polymerase and $1 \mu \mathrm{l}$ of RNaseH were added to each tube. After incubating the reactions at $16^{\circ} \mathrm{C}$ for $2 \mathrm{~h}$, each cDNA was purified and $20 \mu \mathrm{l}$ of each purified cDNA was mixed with $12 \mu \mathrm{l}$ biotin-NTP, $4 \mu \mathrm{l}$ of 10X T7 reaction buffer and 4 $\mu \mathrm{l}$ of 10X enzyme mix reaction buffer, then incubated at $37^{\circ} \mathrm{C}$ for $14 \mathrm{~h}$. After cRNA synthesis, each cRNA preparation was purified and $10 \mu \mathrm{g}$ of each biotinylated cRNA was mixed with $5 \mu \mathrm{l}$ of fragmentation buffer in a final volume of $25 \mu \mathrm{l}$, incubated at $94^{\circ} \mathrm{C}$ for $20 \mathrm{~min}$ and then kept on ice for $5 \mathrm{~min}$. Subsequently, $25 \mu \mathrm{l}$ of each reaction was transferred to another tube containing 78 $\mu \mathrm{l}$ of hybridisation buffer A, $130 \mu \mathrm{l}$ of hybridisation buffer $\mathrm{B}$ and $27 \mu \mathrm{l}$ of water; the reaction was incubated at $90^{\circ} \mathrm{C}$ for $5 \mathrm{~min}$. Each tube was then placed on ice and applied to the Codelink DNA microarray containing around 36,000 genes. The subsequent stages of hybridisation, washing and analysis of each microarray were carried out as detailed in the Codelink Gene Expression System: Single-Assay Bioarray Hybridisation and Detection manual.

\section{DNA microarray analysis}

The gene expression data were normalised using the SVR (Support Vector Regression) method [8], implemented in the GEDI toolbox [9]. More information on normalisation method is available at http://mariwork. iq.usp.br/gedi/. Briefly, SVR is a non-parametric regression, similar to the Loess method; however, it has greater accuracy than the Loess method, therefore, it is a more useful tool to identify differentially expressed 
genes. Identification of these genes was obtained using the ratio of normalised intensities between rhBMP ( 2 or 7) and control (untreated) samples, considering a fold change of $\geq 2.5$. Induced and repressed genes in $\mathrm{C} 2 \mathrm{C} 12$ cells under simultaneous treatment with rhBMP2 and rhBMP7 were classified according to their functions through the FatiGO program (http://bioinfo.cipf.es/babelomicswiki/tool:fatigo).

\section{Real Time RT-PCR}

One microgram of total RNA was treated with $1 \mathrm{U}$ of DNaseI at $37^{\circ} \mathrm{C}$ for $20 \mathrm{~min}$ and at $75^{\circ} \mathrm{C}$ for $10 \mathrm{~min}$. The $\mathrm{RT}$ reaction was carried out at $50^{\circ} \mathrm{C}$ for $2 \mathrm{~h}$ in a $20 \mu \mathrm{lmix}$ of $1 \mathrm{X}$ first strand buffer, $10 \mathrm{mM}$ DTT, $2.5 \mathrm{mM}$ of poly-dT primer (Amersham-Bioscience), $1 \mathrm{mM}$ each of dNTPs, 20 U of RNAseOUT (Invitrogen) and $20 \mathrm{U}$ of Superscript III (Invitrogen). The mixture was then incubated at $70^{\circ} \mathrm{C}$ for $15 \mathrm{~min}$ and incubated with $5 \mathrm{U}$ of $\mathrm{RNaseH}$ at $37^{\circ} \mathrm{C}$ for 30 min and finally incubated at $75^{\circ} \mathrm{C}$ for $10 \mathrm{~min}$. Samples of cDNA were diluted to $100 \mu \mathrm{l}$, and $3 \mu \mathrm{l}$ aliquots of this cDNA solution were used for quantitative PCR using a Light-Cycler Real Time PCR System 7300 (Applied Biosystems). The PCR reaction was carried out in a $12 \mu \mathrm{l}$ mix containing $6 \mu$ l of Sybr ${ }^{\mathbb{B}}$ Green Mastermix (Applied Biosystems), $3 \mu$ l of the cDNA solution and $3 \mu$ lof the appropriate primers in a concentration between 200 to $600 \mathrm{~nm}$ under the following conditions: $2 \mathrm{~min}$ at $50^{\circ} \mathrm{C}, 10 \mathrm{~min}$ at $95^{\circ} \mathrm{C}$, followed by 40 cycles of $15 \mathrm{sec}$ at $95^{\circ} \mathrm{C}$ and $1 \mathrm{~min}$ at $60^{\circ} \mathrm{C}$. Expression values were calculated from threshold cycle at which an increase in reporter fluorescence above baseline signal could first be detected $\left(\mathrm{C}_{\mathrm{T}}\right)$. For data normalisation, three housekeeping genes were used, namely $m G A P D H, m H P R T$ and $m H M B S$, using a calculated factor that was generated by the GeNorm program [10]. Control (untreated) and rhBMP2 and rhBMP7 treated groups were compared using a two-way ANOVA (Bonferroni test) and the GraphPad Prism 4 program. All primers used (Table 1) were validated beforehand according to the method described by Rasmussen [11].

\section{Protein network analysis of gene products which were upregulated by treatment with rhBMP2/7}

Accession numbers for genes validated by real-time RTPCR were searched against the STRING database version 9 (http://string-db.org/) [12] for protein-protein interactions, using a STRING confidence score set to $\geq$ 0.7 (high confidence).

\section{Results}

Gene expression profiles during osteodifferentiation of C2C12 cells induced by rhBMP2 and rhBMP7 were constructed using DNA microarrays

In order to identify novel potential regulators of osteoblastic differentiation, we used DNA microarrays and
RT-qPCR. Total RNA was isolated after $12 \mathrm{~h}$ of treatment with rhBMP2 or rhBMP7 for both DNA microarray and $\mathrm{RT}$-qPCR experiments. In addition, total RNA was collected at $0,4,8$ and $24 \mathrm{~h}$ after stimulation with each of these BMPs for RT-qPCR analysis. Upon treatment of $\mathrm{C} 2 \mathrm{C} 12$ cells with rhBMP2 or rhBMP7, the microarray analysis data resulted in 1,862 and 2,517 upregulated genes, and 1,335 and 1,918 downregulated genes, respectively, considering as significant a fold change of 2.5-fold or higher. Induced and repressed genes were intercepted, resulting in 1,318 induced genes and 704 repressed genes by both rhBMP2 and rhBMP7.

The differentially expressed genes regulated in common by rhBMP2 and rhBMP7 were classified according to their function, as predicted by the FatiGO Data Mining program (http://bioinfo.cipf.es/babelomicswiki/ tool:fatigo), which classifies genes according to Gene Ontology (GO) criteria (cellular component, function and molecular biological process), thereby allowing the selection of 24 genes induced by both rhBMP2 and rhBMP7. These genes, which are related mainly to signal transduction, development, cell differentiation, osteodifferentiation and bone repair, are shown in Table 2, with the fold change for each gene also being shown.

Differential gene expression was validated by RTqPCR. The results represent the mean values of three independent experiments, each of which was performed in triplicate. The relative expression of each gene was calculated as described in the Materials and Methods.

Figure 1 shows the expression profile of 13 genes involved in the transcriptional regulation of several genes, some of which are already known to be involved in the regulation of different cellular processes, while others have not yet been characterised, namely: Runx2, Dlx1, Dlx2, Dlx5, Id1, Id2, Id3, Fkhr1, Osx, Hoxc8, Glis1, Glis3 and Cfdp1. Id1, Id 2 and Id3 correspond to proteins which bind to transcription factors, modifying their ability to bind DNA and affecting the expression of one or more genes. $C f d p 1$ could participate in the complex of proteins that modify the chromatin state, thus regulating the transcription of several genes. All of the other genes presented in Figure 1 code for transcription factors. The first gene is the well-known Runx2, which was induced to similar levels by rhBMP2 and rhBMP7. Runx2 was upregulated four hours after treatment, and the highest level of expression appeared $12 \mathrm{~h}$ after treatment, declining at $24 \mathrm{~h}$, but remaining significantly higher than the control. This same expression profile was observed for $I d 1, I d 2$ and $I d 3$, but, in the case of $I d 2$, treatment with rhBMP7 caused a higher level of expression than rhBMP2 at 4, 8, 12 and 24 h; for $I d 1$ and $I d 3$, there was also a difference in induction over these time periods, but it was lower than that achieved by $I d 2 . D l x 1$ and $D l \times 2$ were induced $4 \mathrm{~h}$ after 


\begin{tabular}{|c|c|c|}
\hline Gene & Forward & Reverse \\
\hline mG3PDH & GATGCCCCCATGTTTGTGAT & GGTCATGAGCCCTTCCACAAT \\
\hline $\mathrm{mHMBS}$ & GCGGAAGAAAACGGCTCAA & TCCCGTGGTGGACATAGCA \\
\hline mHPRT & GTCCCAGCGTCGTGATTAGC & TCATGACATCTCGAGCAAGTCTIT \\
\hline Runx2 & ACCGAGACCAACCGAGTCAT & CTCGGATCCCAAAAGAAGCTT \\
\hline Dlx1 & GTCTGTGCGCCGAAGTCAA & GCCCGGAAGAAGACCATTC \\
\hline Dlx2 & CAGCGGCCTCAACAATGTCT & ATTCGGATTTCAGGCTCAAGGT \\
\hline Dlx5 & GCCTCTCTAGGACTGACGCAAA & TGGTGACTGTGGCGAGTTACA \\
\hline ld1 & GATGGACTCCAGCCCTTCAG & TGGAGAGGGTGAGGCTCTGT \\
\hline $\mathrm{Id} 2$ & GGTGGACGACCCGATGAGT & GCGATCTGCAGGTCCAAGAT \\
\hline Id3 & GAAATCCTGCAGCGTGTCATAG & AAAGCTCCTCTTGTCCTTGGAGAT \\
\hline Osx & TCCCCTTGTCGTCATGGTTAC & TTGAATTTGATCCCAGAGAAAGC \\
\hline Hoxc8 & ATGCCCAGCATACACTCTCTTGT & ATAAATACCAGAGAAGCACCGTGAA \\
\hline Fkhr1 & CCTTTGCCCCAGATGCCTAT & GGGATCAACCGGTGACATAATG \\
\hline Glis1 & AGAAGCCCAACAAGTGCATGTT & GGTCGCTGGAGTTGCTGAAG \\
\hline Glis3 & TGCACCTCTTCCATCTTCTCATT & TTCCCGTTCTTGTGCATATTCAT \\
\hline Cfdp1 & AAGAAGGGTACATTGAGCGGAAA & AGGAGCTCACATTGTCAATAGGATT \\
\hline Lrp6 & ACCAAGGTCCAGGCTCGAA & GCATCTTGTCGTACCATCTCCTIT \\
\hline Dvl1 & AAGAGTGACATGAGTGCCATTGTC & GAAGCCCTCCACGTGTGTGTA \\
\hline Ecsit & AAGCTGTGGTTCACCCGATTC & GGGCAAAGACATCTGGTAGACAGT \\
\hline Pkcd & GTGGTGTTGATTGACGATGATGTAG & ACCCCCATTGAGAAACTCCAT \\
\hline Ltbp2 & AGGAGCCAAGAGTTAAAGAAATCTAAAA & TTTCCCATAGGATAGATGTGCCTAA \\
\hline Grn & CAATGCCCAATGCCATCTG & ACTTCACCTCCTTCACTGGGTATC \\
\hline BMP1 & CCATGTCTCTATTGTACGCGAGAA & AAGATGCCCCTGGAGAATGTG \\
\hline Plod1 & AAACGTGCCCACTATCGACAT & CGGACGACGAAGGCTAGATC \\
\hline Postn & TTAGCATCTTCCTCAGCCTCCTT & GAGCATTITATCCCCAATCAGAA \\
\hline Htra1 & AGCTGAGACCTGGAGAATTTGTAGTT & TAGCGTCTGTCTGAATGTAGTCCAT \\
\hline IGFBP-rP10 & GCTGCAATCACGGAGTTTGTT & GTCTTCTCCGGGCTITCTACAC \\
\hline
\end{tabular}

stimulation with both rhBMPs. $D l x 1$ reached its maximum expression $12 \mathrm{~h}$ after treatment, then decreased to basal levels by $24 \mathrm{~h}$. During this period of time, $D l \times 2$ reached its highest expression level. Dlx5 was similarly upregulated by both rhBMPs, with a slight increase between 4-8 $\mathrm{h}$ and a further increase (5 to 6-fold) at 12 and $24 \mathrm{~h}$. Fkhr1 was induced, displayed its maximum expression level after $4 \mathrm{~h}$ and decreased thereafter to basal levels at $24 \mathrm{~h}$. The expression of Osx began to increase $4 \mathrm{~h}$ after treatment and gradually increased until reaching its maximum level after $24 \mathrm{~h}$; expression levels were similar upon treatment with both proteins. Hoxc 8 expression slightly increased after 4 and $8 \mathrm{~h}$, reached its maximum level at $12 \mathrm{~h}$ and decreased at 24 $\mathrm{h}$ after treatment with rhBMP2, while treatment with rhBMP7 caused increased expression only at 12 and 24 h. Another difference was that, after $12 \mathrm{~h}$ of treatment, rhBMP2 caused greater expression of Hoxc8 than rhBMP7. Glis1 was upregulated at $4 \mathrm{~h}$, and remained at a constant level for up to $12 \mathrm{~h}$, decreasing at $24 \mathrm{~h}$, but, in this case, there was a clearly greater increased expression when $\mathrm{C} 2 \mathrm{C} 12$ cells were treated with rhBMP2 than with rhBMP7. Glis3 was induced after $4 \mathrm{~h}$ of treatment, remained constant for up to $12 \mathrm{~h}$ and decreased at $24 \mathrm{~h}$, but, unlike Glis1, the level of expression achieved by Glis 3 was very similar in cells treated with rhBMP2 or rhBMP7.

The differential expression of the $C f d p 1$ gene is shown in Figure 1. This gene was induced by rhBMP2 at $4 \mathrm{~h}$, was maintained at a constant expression level for up to $8 \mathrm{~h}$, slightly increased at $12 \mathrm{~h}$ and decreased again at 24 $\mathrm{h}$ to similar levels as those detected at 4 or $8 \mathrm{~h}$. On the other hand, the expression of $C f d p 1$ only significantly increased $12 \mathrm{~h}$ after treatment with rhBMP7 but by $24 \mathrm{~h}$ was expressed at a higher level when compared to control.

Figure 2 shows the expression analysis of genes related to cell signalling: Lrp6, Dvl1, Ecsit and PKC $\delta$. The expression of $\operatorname{Lrp} 6$ slightly increased after 4 and $8 \mathrm{~h}$ of treatment with rhBMPs, then reached maximum expression levels at $12 \mathrm{~h}$ and decreased by $24 \mathrm{~h}$. Treatment with rhBMP7 caused a slight increase in Dvl1 expression at $8 \mathrm{~h}$ while rhBMP2 did not generate such a response. Coincidentally, maximum expression was found at $12 \mathrm{~h}$ in cells treated with both recombinant proteins, with slightly decreasing levels until up to $24 \mathrm{~h}$. The expression 
Table 2 Genes selected by DNA microarray analysis during osteodifferentiation of C2C12 cells induced by both rhBMP2 and rhBMP7

\begin{tabular}{|c|c|c|c|}
\hline \multirow[t]{2}{*}{ Accession Number } & \multirow[t]{2}{*}{ Gene } & \multicolumn{2}{|c|}{ Fold Change } \\
\hline & & $\mathrm{rhBMP} 2 / \mathrm{C}$ & $\mathrm{rhBMP7/C}$ \\
\hline NM_009820.1 & Runt related transcription factor 2 (Runx2) & 2.9 & 3.2 \\
\hline NM_010495.1 & Inhibitor of DNA binding 1 (Id1) & 20.4 & 31.7 \\
\hline NM_010496.2 & Inhibitor of DNA binding 2 (Id2) & 5.8 & 88.3 \\
\hline NM_008321.1 & Inhibitor of DNA binding 3 (Id3) & 3.6 & 4.09 \\
\hline NM_010053.1 & Distal-less homeobox 1 (D|x1) & 6.5 & 8.0 \\
\hline NM_010054.1 & Distal-less homeobox 2 (D|x2) & 3.2 & 5.6 \\
\hline NM_010056.2 & Distal-less homeobox 5 (D|x5) & 4.2 & 4.5 \\
\hline NM_130458.1 & Osterix transcription factor (Osx) & 3.7 & 5.5 \\
\hline NM_010466.1 & Homeobox C8 (Hoxc8) & 2.5 & 4.2 \\
\hline NM_147221.1 & GLIS family zinc finger 1 (Glis1) & 176.8 & 131.3 \\
\hline NM_175459.3 & GLIS family zinc finger 3 (Glis3) & 35.5 & 33.3 \\
\hline AF114258.1 & Forkhead protein 1 (FKHR1) & 3.2 & 67.2 \\
\hline NM_011801.1 & Craniofacial development protein 1 (Cfdp1) & 4.3 & 46.3 \\
\hline NM_010091.3 & Dvl1 & 4.3 & 160.2 \\
\hline NM_011103.1 & Protein kinase $C$, delta (Prkcd) & 2.5 & 11.2 \\
\hline NM_012029.1 & Signalling Intermediate in Toll pathway-evolutionarily conserved (Ecsit) & 2.9 & 12.8 \\
\hline NM_008175.2 & Granulin (Grn) & 3.1 & 89.0 \\
\hline NM_008514.1 & Low density lipoprotein receptor-related protein 6 (Lrp6) & 2.7 & 6.5 \\
\hline NM_013589.1 & Latent transforming growth factor beta binding protein 2 (Ltbp2) & 5.3 & 17.6 \\
\hline NM_178929.2 & Kazal-type serine protease inhibitor domain 1 (IGFBP-rP10) & 3.3 & 7.1 \\
\hline NM_015784.1 & Periostin, osteoblast specific factor (Postn) & 2.5 & 14.3 \\
\hline NM_019564.1 & High Temperature requirement 1 (Htra1) & 2.5 & 3.9 \\
\hline NM_009755.2 & Bone morphogenetic protein 1 (Bmp1) & 4.1 & 55.4 \\
\hline NM_011122.1 & Procollagen-lysine, 2-oxoglutarate 5 -dioxygenase 1 (Plod1) & 37.9 & 45.9 \\
\hline
\end{tabular}

of Ecsit increased $4 \mathrm{~h}$ after stimulation, slightly decreased at $8 \mathrm{~h}$ increased again at $12 \mathrm{~h}$ and decreased to basal levels at $24 \mathrm{~h}$. In the case of $P K C \delta$, treatment with rhBMP2 for $4 \mathrm{~h}$ caused greater expression when compared to treatment with rhBMP7. However, at 8 and $12 \mathrm{~h}$, the levels achieved with both treatments were very similar. Finally, at $24 \mathrm{~h}$, greater expression was found in cells treated with rhBMP2, when compared to the control and to treatment with rhBMP7, but the expression of this gene decreased at this time point.

Upon analysis of the DNA microarrays, seven genes related to the extracellular matrix were selected to be examined by RT-qPCR, namely $L t b p 2$, Grn, Postn, Plod1, BMP1, Htra1 and IGFBP-rP10; the results are shown in Figure 3. The expression of $L t b p 2$ increased upon BMP stimulation $4 \mathrm{~h}$ after treatment, maintained a constant level of expression for up to $12 \mathrm{~h}$, but decreased after $24 \mathrm{~h}$. As can be observed, slightly higher expression was found in cells were treated with rhBMP2 compared to cells treated with rhBMP7. A similar expression profile was found for Grn, Postn, Plod1 and $B M P 1$. Coincidentally, increased expression of these four genes occurred after $12 \mathrm{~h}$ of stimulation with rhBMP2 and rhBMP7 and continued to increase at 24 h. Upon incubation with both rhBMPs, the expression of Htra 1 began to gradually increase at $4 \mathrm{~h}$, was maintained at this level at $8 \mathrm{~h}$, reached a peak at $12 \mathrm{~h}$ and fell to basal levels at $24 \mathrm{~h}$. As can be seen in Figure 3, the expression of IGFBP-rP10 was induced at $4 \mathrm{~h}$ after treatment and remained at a constant level at $8 \mathrm{~h}$ and increased again at $12 \mathrm{~h}$, with higher levels in cells incubated with rhBMP2 than with rhBMP7. At $24 \mathrm{~h}$, the level of expression induced by rhBMP2 was very similar to that obtained at $12 \mathrm{~h}$, or remained virtually the same, except for the fact that the expression induced by rhBMP7 at $24 \mathrm{~h}$ was about twice the level seen at $12 \mathrm{~h}$.

\section{Discussion}

Our DNA microarray analysis refers to treatment of pre-myoblastic and pre-osteoblastic $\mathrm{C} 2 \mathrm{C} 12$ cells with BMP2 and BMP7 for a period of $12 \mathrm{~h}$. The choice of this period relies on the fact that expression of the genes which induce $\mathrm{C} 2 \mathrm{C} 12$ cells to differentiate into osteoblast-like cells is found upon treatment with rhBMP2 for 8 and $16 \mathrm{~h}$ [13]. The cut-off of 2.5 -fold change was chosen due to the fact that Runx2, which is widely known to be activated by both rhBMPs during osteodifferentiation [14], presented a fold change of 2.94 

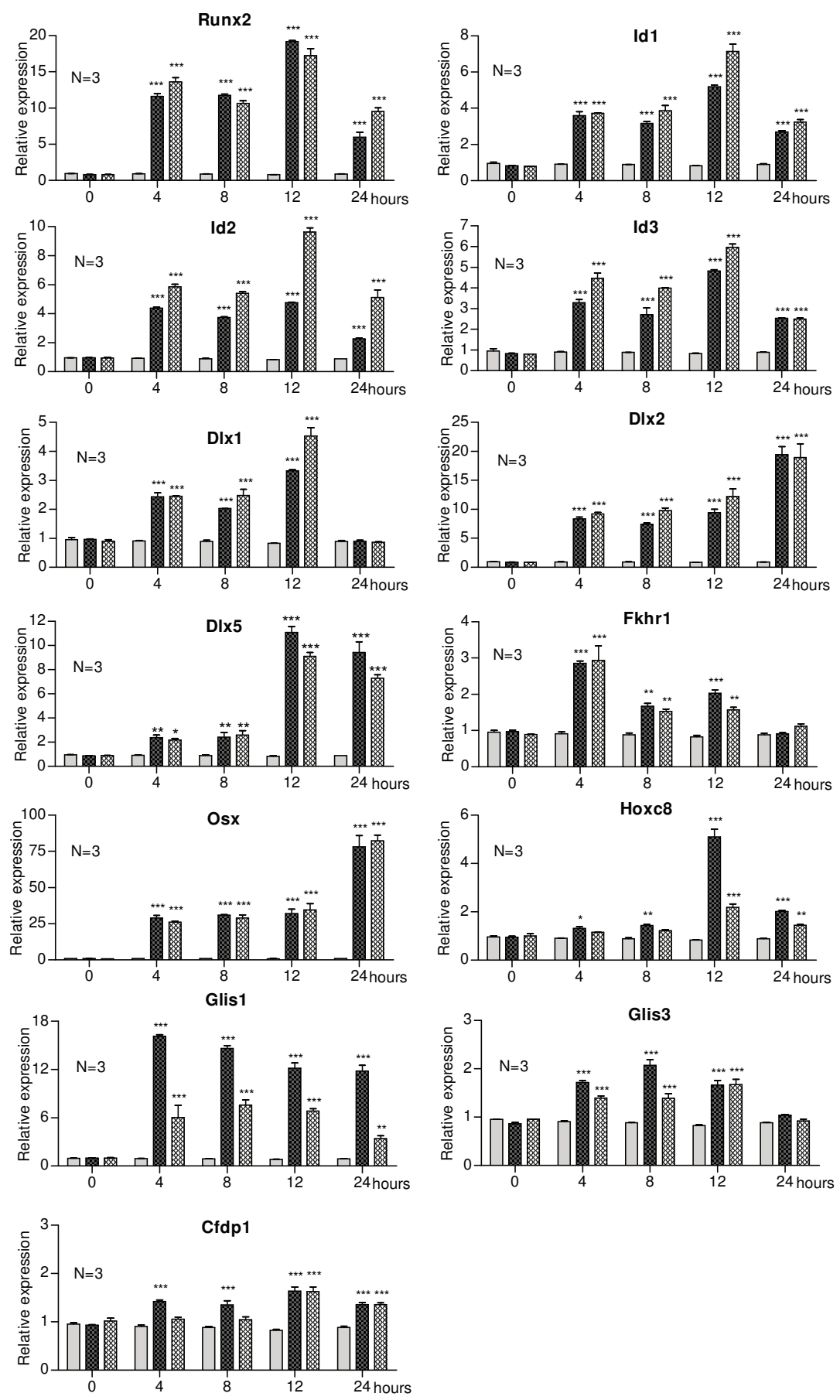

$\square$ Control $\mathrm{AnBMP2}$ rhBMP7

Figure 1 Relative expression levels of genes related to transcription in $\mathrm{C} 2 \mathrm{C} 12$ cells treated with rhBMP2 and rhBMP7. Cells were seeded and grown for $24 \mathrm{~h}$ at which point the medium was replaced by DMEM containing 5\% FCS in the presence or absence of rhBMP2 (200 $\mathrm{ng} / \mathrm{ml})$ or rhBMP7 $(200 \mathrm{ng} / \mathrm{ml})$. RNA was isolated $0,4,8,12$ and $24 \mathrm{~h}$ after stimulation. Subsequently, expression levels were measured by quantitative real time RT-PCR. The asterisks correspond to the statistical analysis (two-way ANOVA, Bonferroni test) between control and treatment $\left({ }^{*} p<0.05 ;{ }^{* *} p<0.01 ; * * p<0.001\right)$. 


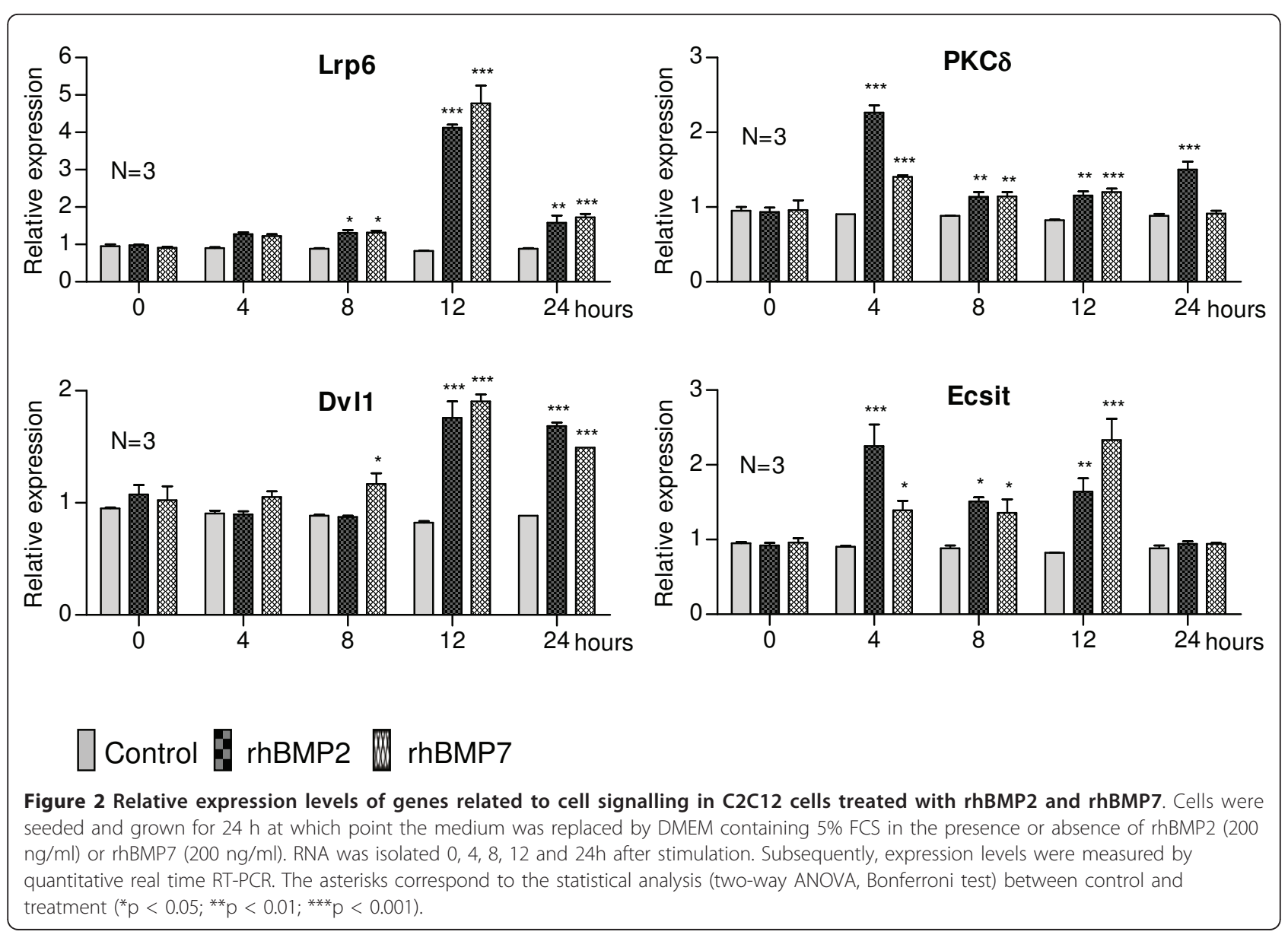

and 3.17 upon treatment with rhBMP2 and rhBMP7, respectively (Table 2). Although downregulated genes are also of interest, they were not selected due to the fact that, in $\mathrm{C} 2 \mathrm{C} 12$ cells, most of these genes would probably be more directly involved in myogenesis rather than in osteogenesis, but this does not rule out the interest in their analysis in future research. Therefore, our main interest was focused on genes which are upregulated by both rhBMPs and that could be involved in osteodifferentiation. Particularly, we focused on genes which are induced at the very beginning of osteoblast differentiation, which encompasses the first $24 \mathrm{~h}$ following BMP receptor activation, a period in which the key process for commitment to the osteoblast lineage occurs in precursor cells.

The genes selected from the microarray analysis were classified according to their function, 13 of which are involved in transcription, four in cell signalling and seven are related to the extracellular matrix. The mRNA levels of their corresponding genes, determined by qRTPCR, were analysed at different time points $(0,4,8,12$ and $24 \mathrm{~h}$ ) following treatment with both BMPs, each displaying its own expression profile, which was compared to that of the other.

\section{Transcription factors and related proteins}

Most biological processes, including osteoblastic differentiation, are dependent upon transcriptional activation of several effector genes. The signal generated upon interaction between BMPs and their receptors causes activation and repression of a number of genes coding for transcription factors and, also, for proteins, which bind to these factors, thereby positively or negatively modifying their function. The expression profile of 13 genes related to transcription was examined by RTqPCR (Figure 1).

Runx2

As expected, Runx2 was induced upon $4 \mathrm{~h}$ of treatment with both rhBMPs. This gene is at the end of the Smad protein pathway, and, as recently found [7], the MAPK pathway. As such, its product is a very important transcription factor for both chondrogenesis and osteogenesis during the development of the skeleton [14]. In addition to BMPs, Runx2 is also induced by TGF $\beta$ and FGF2, which are also known to be involved in bone formation [15]. Runx $2^{-/-}$knock-out mice show a complete lack of functional osteoblasts, and are devoid of mineralised bone or hypertrophic cartilage [16]. Moreover, 


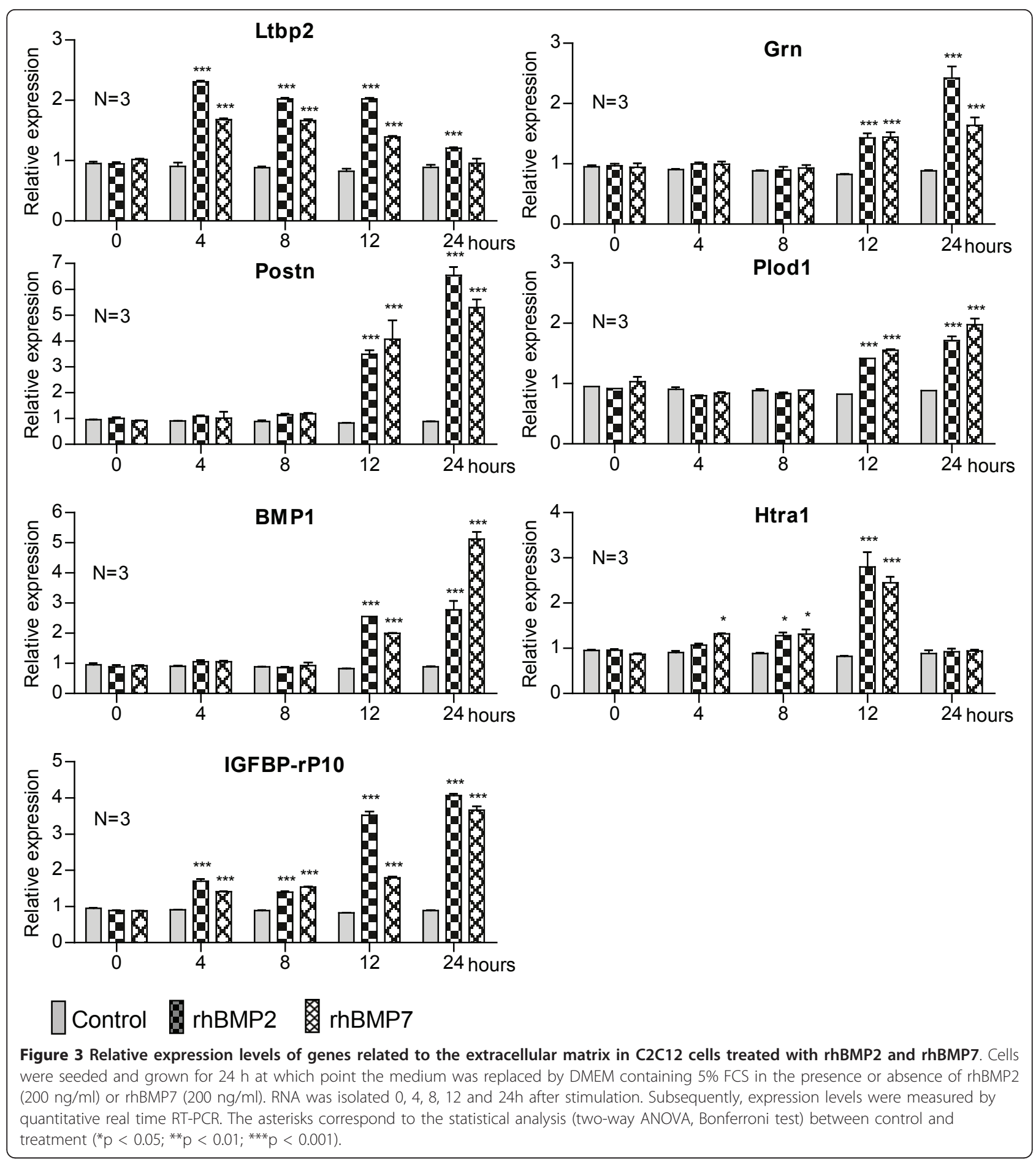

mutations in this gene result in cleidocranial dysplasia, which is characterised by bone alterations [17]. BMP2 and Runx 2 act synergistically, stimulating osteodifferentiation both in vitro and in vivo [18]. Indeed, Runx2 phosphorylation, through MAPK activation by FGF2, seems to be important for the induction of osteocalcin expression [19]. Therefore, the importance of Runx2 in osteoblast differentiation and bone formation is clear: it represents a hub gene in bone formation by regulating osteoblast genes (Figure 4), along with the fact that this gene is differentially expressed in $\mathrm{C} 2 \mathrm{C} 12$ cells treated with rhBMP2 and rhBMP7 (Figure 1), conferring greater confidence with respect to the other genes selected in this study. 


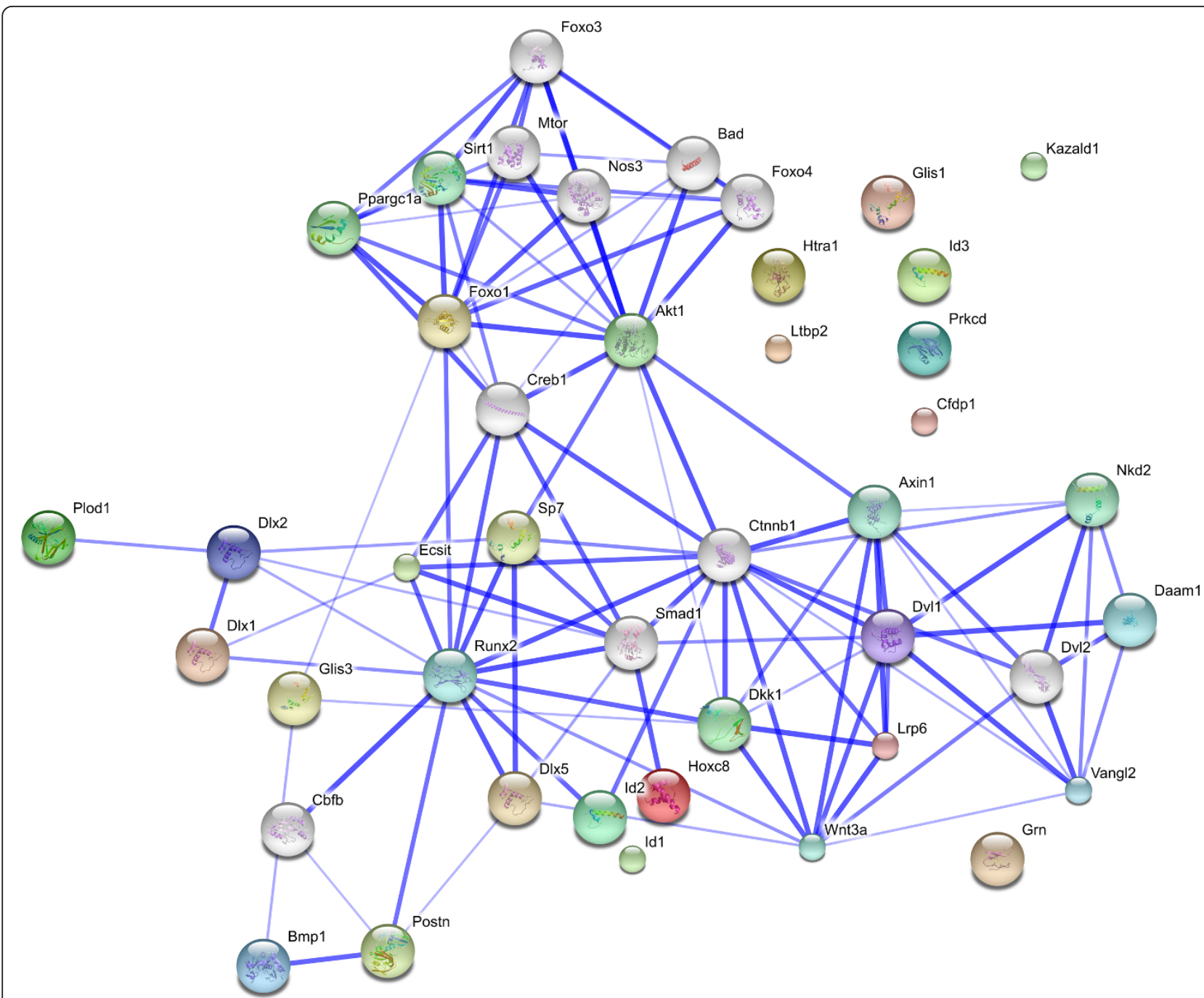

Figure 4 Network of upregulated genes in C2C12 cells treated with rhBMP2 and rhBMP7 using the STRING 9.0 pathway analyzer STRING 9.0 is a database of known and predicted protein interactions. The interactions may be physically direct or indirect (functional). The list of protein names are inserted as input and the organism to be analyzed is selected in a user-friendly web-browser interface. The network, composed of the uploaded proteins, is constructed based on four different sources: genomic context, high-throughput experiments, coexpression and scientific reports (http://string-db.org/). The upregulated genes found in each group (C2C12 cells treated with rhBMP7 or rhBMP2) were matched and classified according to a pre-described interaction (activation, repression, or predicted interaction). The circles represent the genes and the blue edges represent the interaction between them. The edges are based on proteins being co-mentioned in scientific publications as well as their association in curated databases. The edge thickness is directly proportional to the degree of evidence available, with lack of evidence for interactions in the literature being represented as no edges among the genes. Runx2: Runt Related Transcription factor 2; Dlx1/2/5: Distal-less homeobox 1/2 and 5;Id1/2/3: Inhibitor of DNA binding 1/2 and 3; Sp7, an alternative name for Osterix: Transcription factor Sp7; Hoxc8: Homeobox protein Hox-C8; Fkhr1: Forkhead protein FKHR1; Glis1/3: Gli homologous protein 1; Cfdp1: Craniofacial development protein 1; Lrp6: Low-density lipoprotein receptor-related protein 6; Segment polarity protein dishevelled homolog DVL-1; Ecsit: Evolutionarily conserved signaling intermediate in the Toll pathway, mitochondrial; PKCd: Protein kinase C, delta type; Ltbp2: Latent-transforming growth factor beta-binding protein 2; Grn: Granulin; BMP1: Bone Morphogenetic Protein 1; Plod1: Procollagen-lysine,2-oxoglutarate 5-dioxygenase 1; Postn: Periostin; Htra1: Serine protease HTRA1; Kazald1: Kazal-type serine protease inhibitor domain-containing protein 1 (IGFBP-rP10); Wnt3a: Protein Wnt-3a; Dkk1: Dickkopf-related protein 1 and Ctnn1b: Catenin beta-1.

\section{Id 1, Id 2 and Id 3}

The Id1, Id 2 and $I d 3$ genes were induced by treatment of $\mathrm{C} 2 \mathrm{C} 12$ cells with both rhBMPs (Figure 1). Id genes encode proteins called ID (inhibitor of DNA binding), a group of proteins which belong to the basic helix-loop- helix (bHLH) family, but lack the basic region, which is important in DNA binding and transcriptional activation. Evidence is available showing that Id1 forms heterodimers with E12/E47 and prevents MyoD from forming complexes with E12/E47 in myoblasts [20,21]. 
The Id proteins are targets for BMP family members, particularly for BMP2 [22,23]. Interestingly, a Smad phosphatase, named C-terminal domain phosphatase (SCP1) inhibited the activation of Id1, Id2 and Id3, impairing osteoblastic differentiation in $\mathrm{C} 2 \mathrm{C} 12$ cells [24]. These effects on Id genes expression were only described for cells treated with BMP2, as no report is yet available for BMP7-treated cells. Together, the results we present here and those of others [21] indicate that these Id genes are, in fact, activated during osteoblastic differentiation upon treatment with both rhBMP2 and rhBMP7.

\section{$D / x 1, D / x 2$ and D/x5}

Treatment with rhBMP2 and rhBMP7 induced the homeobox gene family related to the distal-less (Dll) gene of Drosophila (Dlx1, Dlx 2 and $D l x 5$ genes, Figure 1) [25]. The $D l x$ genes control the expression of various genes involved in the development of invertebrates and vertebrates. In mammals, they are expressed in the nervous system derived from the neural crest and brachial arches, participating in the development of the brain, craniofacial structures and the axial and appendicular skeleton [25]. In view of these characteristics, the Dlx1, Dlx2 and Dlx5 transcription factors may be very important during osteoblastic differentiation. Particularly, evidence is available indicating that $D l \times 5$ is a direct target for BMPs. During osteogenic transdifferentiation of $\mathrm{C} 2 \mathrm{C} 12$ cells, it has been demonstrated that Dlx 5 regulates the expression of Runx2 in cells treated with rhBMP2, but not with TGF $\beta 1$ [26] (interaction between Runx2 and Dlx5, as shown in Figure 4). This, together with the ability of BMP2 to induce the expression of alkaline phosphatase $(A L P)$ and $O s x$ in Runx $2^{-1-}$ knockout mouse cells, could represent an additional pathway by which Dlx 5 modulates the expression of Runx2 and Osx. Dlx5, but not Runx2, is essential for the expression of Osx in cells treated with BMP2 [15], indicating that Dlx 5 regulates the expression of Osx independently of Runx2. These data are consistent with the $D l x 5$ gene expression profile obtained here for both rhBMP treatments, so it is likely that Dlx1 and Dlx2 could also participate in this or similar mechanisms.

\section{Osx}

Osx, a zinc finger-containing transcription factor, was the gene with the greatest relative induction level upon treatment of $\mathrm{C} 2 \mathrm{C} 12$ cells with rhBMPs. This gene is expressed in all bones, and Osx ${ }^{-/}$knock-out mice lack mineralised bone [27]. It has been suggested that Osx acts in the terminal differentiation of osteoblasts to operate the distinction between chondrogenic and osteogenic pathways while Runx 2 acts upstream, in the commitment of mesenchymal cells to chondrocytes or osteoblasts [28]. Osx regulates the expression of important genes in bone, such as those coding for bone sialoprotein (BSP), osteocalcin, osteonectin and osteopontin [29]. As mentioned above, Dlx5 regulates the expression of Osx (also known as Sp7, node in Figure 4). Interestingly, confirming data from the literature on the expression profile of $D l x 2$ and $D l x 5$, it may be noted that the $O s x$ transcript significantly increased between 12 and $24 \mathrm{~h}$, which may be related to the increase in $D l \times 2$ and $D l \times 5$ expression during the same period of time, revealing that although Osx first requires Dlx5, later on, Dlx2 could also be important for resuming osteodifferentiation (Figure 1).

\section{Fkhr1}

The Fkhr1 transcription factor, which we found to be differentially expressed in $\mathrm{C} 2 \mathrm{C} 12$ cells, is able to stimulate alkaline phosphatase gene expression, increasing its activity. This protein and the family of factors to which it belongs are involved in regulating processes such as the cell cycle, apoptosis, glucose metabolism, cell differentiation and embryogenesis [30]. Recently, a study demonstrated that Fkhr1 is involved in osteoblastic differentiation of MC3T3-E1 cells, since Fkhr1 knockdown cells failed to perform matrix mineralisation, and immunoprecipitation assays suggest an interaction between Fkhr1 and the RunX2 promoter [31]. Moreover, increased $F k h r l$ expression and ALP activity were detected six days after treatment of hMSC (human marrow cells) with BMP2 [32]. We found that the expression fell to basal levels $24 \mathrm{~h}$ after treatment in both BMP2 and BMP7-treated cells (Figure 1), while the ALP activity began to gradually increase after $48 \mathrm{~h}$ of treatment (data not shown). A few explanations for this may be envisaged, namely: a) $A L P$ expression is activated by other transcription factors, such as Runx2 and Dlx5; b) the decrease in the level of $F k h r 1$ transcripts does not mean that the same occurs at the protein level; 3) the Fkhr1 transcript level could increase again $24 \mathrm{~h}$ after stimulation.

Hoxc8

Hoxc8 belongs to the family of conserved Hox genes, which are expressed in the neural tube, cartilage and bone [33]. Hoxc8 binds to the osteopontin (Spp1) and osteoprogeterin $(O P G)$ promoters, acting as a transcriptional repressor. We showed that Hoxc8 was induced by rhBMP2 between 4 and $24 \mathrm{~h}$, and by rhBMP7 between 12 and 24 h (Figure 1). Despite the role of Hoxc 8 in the inhibition of osteoblastogenesis, evidenced by stimulation of Smad6 expression in BMP2-treated cells [34], its expression could be explained by a negative feedback loop, regulating the activated Smads, similar to what occurs in in vivo bone metabolism. Recently, it has been reported that BMP2 regulates the expression of miR$199 \mathrm{a}^{*}$ microRNA, which, in turn, downregulates the expression of Smad1. Therefore, the increased expression of Hoxc8, caused by BMPs, may be related an 
inhibition in Smad1 function (Figure 4) additionally caused by miRNA-199a* [35]. It is interesting to note that a high fold-induction of Hoxc8 was obtained in rhBMP2-treated cells, whereas only slightly increased expression was observed for rhBMP7-treated cells, when compared to the control. This suggests that the difference in receptor binding between each BMP implies not only common intracellular messengers, but also activation of different intracellular proteins which may be responsible for this difference in expression levels.

\section{Glis1 and Glis3}

rhBMP2 and rhBMP7 also induced the Glis1 and Glis3 (Gli similar) genes (Figure 1), both of which code for transcription factors belonging to the family of Krüppellike zinc finger proteins [36]. Glis1 and Glis3 contain five Cys2-His2-type zinc-finger motifs which exhibit high homology with those of Gli. However, Glis and Gli proteins exhibit low sequence homology outside their zinc-finger domain. Deletion analysis demonstrated that Glis proteins contain both repressor and activator domains, suggesting that they may function as positive, as well as negative, regulators of gene transcription, and evidence is available suggesting that Glis3 participates in various stages of organogenesis [15]. The expression of Glis1 has been detected during embryogenesis in craniofacial regions, brachial arches and kidney somites [36]. Glis3 has recently been shown to operate synergistically with BMP2 and Shh in osteoblastic differentiation of C3H10T1/2 mesenchymal cells, inducing the expression of FGF18 [37], indicating that this factor may be important during osteodifferentiation. Here, we show that Glis1 expression increased upon treatment with rhBMPs between 4 and $24 \mathrm{~h}$, (Figure 1), resulting in a greater transcript level increase in cells treated with rhBMP2. To date, no evidence is available relating Glis1 with osteodifferentiation induced by BMPs, but its role could possibly be similar to that of Glis3, due to the high homology between these genes. Undoubtedly, in view of the scarce knowledge on the potential role of these transcription factors in osteoblastic differentiation, future studies should be directed to clarify their importance in this cellular process.

\section{Cfdp 1}

$C f d p 1$ expression was induced earlier by rhBMP2 (4-24 h) when compared to rhBMP7 (12-24 h) (Figure 1). Cfdp1 has been detected in some tissues, particularly in teeth and bones. This protein contains a domain called BCNT-c (Bucentaur), which displays homology to one of the proteins constituting the yeast Swr1 complex, which modifies the chromatin state, thereby transcriptionally regulating several genes. $C f d p 1$ was cloned from a mouse library, and the equivalent region in the human genome was found to be associated with craniofacial syndromes. The specific function of Cfdp1 is unknown, but it is presumed to be important during embryogenesis [38]. Evidence is available indicating that Cfdp1 participates in tooth development [39] and could play a similar function during bone formation. Further investigation is necessary to establish the actual role of Cfdp1 in osteogenesis.

\section{Genes involved in cellular signalling}

BMP-activated cell signalling involves the Smad proteins [40]. Interestingly, our analysis of microarrays generated four candidate genes which participate in other pathways, such as Wnt (canonical and non-canonical) and Toll, indicating that these pathways could interact and take part during osteoblastic differentiation. Figure 2 shows a similar expression profile for the Lrp6 and Dvl1 genes upon treatment with rhBMPs. These genes participate in canonical Wnt signalling [41], with evidence showing their relationship with osteogenesis $[42,43]$. Lrp $^{-1-}$ knock-out mice display reduced vertebral trabecular bone volume (TBV), demonstrating the importance of LRP6 in bone formation [44]. Moreover, it has been shown that this co-receptor participates in somitogenesis and osteogenesis [45]. Dvl1 participates, along with other proteins, in the stabilisation of $\beta$-catenin, thus inhibiting the activity of GSK3 $\beta$ kinase [46]. Some data suggest that Dvl1 and? other components of Wnt signalling are activated during bone regeneration and that, particularly, the Dvl isoforms (1,2 and 3) could be important in the proliferation and differentiation of chondrocytes [41]. The increased expression of Lrp6 and Dvl1, observed here, could mean that treatment of C2C12 cells with rhBMPs leads to increased expression of genes related to the signalling, thereby intensifying the effect initially induced by BMPs. In this respect, using $\mathrm{C} 2 \mathrm{C} 12$ and $\mathrm{C} 3 \mathrm{H} 10 \mathrm{~T} 1 / 2$ cells, a synergy has been shown between $\beta$-catenin and BMP2 to promote osteodifferentiation [47]. Also, it is possible that $\beta$-catenin, along with TCF1, may increase Runx2 expression [48]. Ecsit

Increased expression of Ecsit was observed between 4 and $12 \mathrm{~h}$ of treating $\mathrm{C} 2 \mathrm{C} 12$ cells with BMPs (Figure 2). Ecsit participates in the Toll pathway, which regulates pro-inflammatory genes. Ecsit also participates in BMP/Smad signalling, interacting with Smad1 and Smad4 and activating the expression of Tlx2 and other genes [49]. During embryogenesis, the Toll and BMP/ Smad pathways interact for dorsoventral axis formation. On the other hand, Ecsit ${ }^{-/-}$knock-out mice displayed alterations in epiblast and mesoderm formation, dying at embryonic day 7.5 (E7.5) [50]. The exact mechanism by which this protein could be involved in osteoblastic differentiation is unknown, requiring further analysis, but its interaction with the Smad1/4 proteins, and possibly with RunX2 (Figure 4), which 
are both known to be involved in osteodifferentiation, suggests that Ecsit is part of this cellular process, making it likely that the Toll pathway could also be involved in osteoblast differentiation.

\section{$P K C \delta$}

Another gene associated with cell signalling, which we found to be induced by BMPs and validated by RTqPCR, is $P K C \delta$. The enzyme encoded by this gene belongs to the protein kinase $\mathrm{C}$ (PKC) family, which consists of 11 members [51]. Recently, using ST2 cells, it has been shown that $\mathrm{PKC} \delta$ activation is induced by Wnt3a through the canonical pathway, and also by the non-canonical Wnt pathway through Wnt7b in ST2 and $\mathrm{C} 3 \mathrm{H} 10 \mathrm{~T} 1 / 2$ cells. These results indicate the involvement of $\mathrm{PKC} \delta$ during osteodifferentiation in these cells, which could indicate that Wnt7b and $\mathrm{PKC} \delta$ regulate the onset of Osx expression [52]. Another study showed activation of the PKC pathway in MC3T3 and C2C12 cells treated with FGF2, with $\mathrm{PKC} \delta$ being one of the key isoforms involved in FGF2-stimulated Runx2 expression [15].

\section{Proteins associated with the extracellular matrix}

Osteoblasts secrete an extracellular matrix (ECM) formed by various proteins, some of which directly participate in mineralisation of the osteomatrix [19]. For this reason, seven genes representing secreted proteins, with the exception of Plod1, an intracellular enzyme, were analysed. Figure 3 shows that the expression of $L t b p 2$ increased upon treatment with rhBMPs. This protein is part of the latent TGF $\beta$ complex, placing it in the ECM. TGF $\beta$ is activated upon removal from this complex [53]. A possible relationship between Ltbp2, TGF $\beta$ and rhBMPs induced transdifferentiation of C2C12 cells, which may represent, in part, what occurs in bone metabolism, since TGF $\beta$ participates in osteoclastogenesis, regulating the expression of osteoprotegerin (OPG) and the receptor activator of the $N F-\kappa B$ ligand $(R A N K L)$ in osteoblasts and, also, the receptor activator of $N F-\kappa B$ (RANK) in osteoclasts. Therefore, it is important that TGF $\beta$ be released from this latent complex in order to exert its effect [54].

\section{Grn, Postn and Plod1}

Coincidentally, our results show that Grn, Postn, Plod1 and BMP1 were induced between 12 and $24 \mathrm{~h}$ after treatment with rhBMPs. Grn (granulins) are proteins involved in inflammation, repair and remodeling of injured tissues. Although the function of Grn in osteodifferentiation is unknown, it has an osteoclastic origin [55]. Possibly, Grn could participate in bone remodeling, but, obviously, further studies should be carried out to investigate, in more detail, the functions of these proteins in bone tissue. Postn was isolated from osteoblasts as a specific factor, shown to be preferentially expressed in the periosteum. The function of Postn is related to recruitment, adhesion and extension of osteoblasts [13]. Interestingly, the expression of Postn began to increase after $12 \mathrm{~h}$ and progressively increased up to $24 \mathrm{~h}$, indicating that the cells were beginning to display characteristics found in differentiated osteoblasts. Plod1 is not secreted, as it is an intracellular enzyme involved in lysine hydroxylation of type I collagen, the main protein present in bone. In agreement with our results, increased expression of Plod1 was obtained during differentiation of bone marrow stromal cells (BMSCs) and normal skin fibroblasts (NSFs) [56]. Therefore, increased expression of Plod1 during osteoblastic differentiation implicates a stabilisation of collagen type I, which may indicate the beginning of extracellular matrix formation in osteoblasts. BMP1 is an important metalloproteinase in morphogenetic processes in several species. During ECM formation, BMP1 performs the processing of precursor molecules, rendering them into functional ECM components. The substrates of BMP1 include pro-collagens, proteoglycan precursors and proteins associated with ECM mineralisation of bone and teeth. Some substrates are members of the latent complex of TGF $\beta$ family members, such as TGF $\beta 1$, BMP2 and BMP4 [57]. Recent evidence has shown that BMP1 cleaves LTBP molecules, releasing the latent complex of TGF $\beta 1$-LAP from the ECM; subsequently, the LAP protein (latencyassociated peptide) is cleaved by another protease, resulting in the activation of TGF $\beta$ [58]. Our results show the same expression profile for LTBP2 and BMP1 upon induction by rhBMP2 and rhBMP7, associating them with ECM formation and osteoclastogenesis and indicating that both proteins participate in the regulation of TGF $\beta 1$, which is known to be important in such processes.

\section{Htra1}

Htra1 is a family of serine peptidases. It has recently been demonstrated that over-expression of Htral during osteoblastic differentiation of 2T3 cells causes inhibition of ECM mineralisation, suggesting that this may be due to one of three different causes: a) Htra1 modulates the expression of specific osteoblast genes; b) Htra1 alters the activity TGF $\beta /$ BMP pathway; or c) Htra1 cleaves proteins that regulate ECM differentiation and/or mineralisation [59]. Inhibition of ECM mineralisation in these cells by Htra1 could represent a mechanism to control the speed at which the mineralisation process occurs, but more evidence is required to confirm this hypothesis. The possible effect of Htra1 in the ECM mineralisation of $\mathrm{C} 2 \mathrm{C} 12$ and/or other pre-osteoblastic cells should be further examined.

\section{IGFBP-rP10}

IGFBP-rP10 is a member of the insulin growth factor binding protein (IGFBP) family. These proteins are 
involved in the growth and maturation of various tissues through their association with ECM proteins, mediating the access, migration and cellular chemotaxis. IGFBPs bind to integrins, possibly modulating the TGF $\beta$ and Wnt pathways. According to our results, rhBMP2 is able to induce the expression of IGFBP-rP10 in different cell lines, in addition to $\mathrm{C} 2 \mathrm{C} 12$ cells, rendering it very likely that IGFBP-rP10 actively participates in the differentiation and proliferation of osteoblasts during bone formation and bone regeneration [60]. The mechanism by which this protein is induced by BMP2 and BMP7 and how it is involved in these cellular processes represents an interesting challenge which should be faced in the future.

In summary, using DNA microarrays, we have described the pattern of expression of genes which are induced during transdifferentiation of pre-myoblastic C2C12 cells during $24 \mathrm{~h}$ of treatment with rhBMP2 and rhBMP7. A total of 1,318 genes were found to be induced by both rhBMPs which could be involved in osteoblastic differentiation, twenty-four of which were confirmed through RT-qPCR after 4, 8, 12 and 24h of treatment, resulting in 13 transcription-related genes (Runx2, Dlx1, Dlx2, Dlx5, Id1, Id2, Id3, Fkhr1, Osx, Hoxc8, Glis1, Glis3 and Cfdp1) which were induced between 4 and $24 \mathrm{~h}$ after treatment. Four of the genes identified (Lrp6, Dvl1, Ecsit and $P K C \delta)$ are implicated in cell signalling, displaying a more heterogeneous pattern of expression, and seven are ECM-related genes ( $L t b p 2$, Grn, Postn, Plod1, BMP1, Htra1 and IGFBP-rP10), which were preferentially activated after $12 \mathrm{~h}$ of treatment. Our results revealed some genes which were already known to be activated by BMP2. However, we found that many of them were also upregulated by treatment with rhBMP7, thus representing a novel subset of genes related with BMP7-induced differentiation of precursor cells into osteoblasts: Hoxc8, Glis1, Glis3, Ecsit, PKCd, LrP6, Dvl1, Grn, BMP1, Ltbp2, Plod1, Htral and IGFBP-rP10. Fifteen genes were upregulated in the early period (during the first $12 \mathrm{~h}$ ) while nine genes were upregulated at a later period (between 12 and $24 \mathrm{~h}$ ). Among the downregulated genes, MyoD showed a decreased abundance in mRNA relative expression (data not shown), which is explained by the fact that, in the absence of BMPs, this muscular satellite cell line would be programmed to differentiate into myoblasts [20]. Currently, we do not know whether the increased expression of genes at later stages was merely due to the indirect downstream effects of BMP/SMAD signalling as a result of earlier gene (for example, Ids) expression changes. Subsequent studies may elucidate whether the products of these upregulated early genes are responsible for inducing the expression of later genes.
The network analysis of the upregulated genes showed a high connectivity for most of them, with some hubs being distinguished by having six interactions or more, namely a) RunX2, a well-known player in osteoblastogenesis; b) Smad 1, an intracellular transducer of BMP proteins; c) Akt1, a kinase recently found to induce Osx transcription, showing evidence for crosstalk between BMP- Smads and PI 3-kinase/Akt signalling [61]; and d) the Dvl1/Ctnnb1 ( $\beta$-catenin 1 ) axis, both of which belong to the Wnt pathway. $\beta$-catenin 1 is described to be activated upon BMP2 treatment in C3H10T1/2 cells, playing a role in the Wnt-independent pathway mechanism of bone differentiation [62]. These data suggest that the abovementioned genes, despite belonging to distinct pathways, are related to each other in BMP-driven osteoblastogenesis.

It is noteworthy that the results presented here apply to this model of $\mathrm{C} 2 \mathrm{C} 12$ osteoblastic differentiation, which may or may not be identical to that of other types of osteoblastic progenitors, due to the availability of BMP receptors on their surface and on how capable they are of triggering intracellular downstream pathways.

BMP2 and BMP7 both signal through the ALK2 and ALK3 receptors; however, BMP7 predominantly signals via the ALK2 receptor. This alternative signalling mechanism might account for some of the differences in the level of gene expression reported following BMP2 and BMP7 stimulation. The fact that there are differences in the levels of gene expression induced by BMP2 and BMP7 was proven, in vivo, to be due to different biological steps of activation of differentiation. Thus, while BMP2 plays a role in the early stages of osteoblastic differentiation, BMP7 participation is more delayed, sustaining osteoblast maturation, rather than triggering the initial differentiation signal [63]. Another possibility is the existence of unknown receptors or other pathways directly modulating the action of each BMP, as already described for MAPK and/or indirectly, as described by the Wnt pathway (the node representing the Wnt3a protein was found to interact with Lrp6, Ctnnb1, Dvl1, Dkk1 and Dlx5 in Figure 4) [64]. Therefore, subsequent studies should address whether BMP7 signalling through the ALK2 receptor may generate differences in gene expression for Id2 and Dvl1 (and other genes), as compared with BMP2 signalling.

Our findings are relevant to better understanding the molecular basis for BMP-induced osteogenesis during development and the bone healing processes; however, further studies are still required to investigate the intricate network of pathways triggered by these cytokines.

\section{Acknowledgements}

We would like to thank Renato Milani (Institute of Biology - Campinas State University) for the design of Figure 4 and the excellent technical assistance 
provided by Zizi de Mendonça, Sandra Regina de Souza, Debora Cristina da Costa and Ricardo Krett de Oliveira. The financial support of the Federal Brazilian agencies (FINEP, CNPq and CAPES) and of BNDES (National Bank for Social Economical Development), the São Paulo State Research Foundation (FAPESP) and the Ministries of Health (MS-DECIT) and Science and Technology (MCT) are also acknowledged.

\section{Author details}

${ }^{1}$ Chemistry Institute, Department of Biochemistry, Cell and Molecular Therapy Centre (NUCEL), University of São Paulo, Avenida Prof. Lineu Prestes, 748 Bloco 9S, São Paulo, SP 05508-000, Brazil. 'Institute of Mathematics and Statistics, Department of Computer Science, University of São Paulo, Rua do Matão 1010, São Paulo, SP, 05508-090, Brazil. ${ }^{3}$ National Institute of Metrology, Standardization and Industrial Quality (INMETRO), Bioengineering Sector, Duque de Caxias, RJ, CEP 25250-020, Brazil.

\section{Authors' contributions}

JCBV has made substantial contributions to the conception and design of the study. AF has made contributions to the analysis and interpretation of mathematical results. EH has made contributions to the analysis and interpretation of biological data. JMG and MCS have discussed the biological results. MCS has directed the work. JCBV, AF, EH, MJG and MCS critically revised the manuscript for important intellectual content. All authors read and approved the final manuscript.

\section{Competing interests}

The authors declare that they have no competing interests.

Received: 6 October 2010 Accepted: 26 September 2011 Published: 26 September 2011

\section{References}

1. Sieber C, Kopf J, Hiepen C, Knaus P: Recent advances in BMP receptor signaling. Cytokine Growth Factor Rev 2009, 20(5-6):343-355.

2. Abzhanov A, Rodda SJ, McMahon AP, Tabin CJ: Regulation of skeletogenic differentiation in cranial dermal bone. Development 2007, 134(17):3133-3144.

3. Gimble JM, Morgan C, Kelly K, Wu X, Dandapani V, Wang CS, Rosen V: Bone morphogenetic proteins inhibit adipocyte differentiation by bone marrow stromal cells. J Cell Biochem 1995, 58(3):393-402.

4. Deschaseaux F, Pontikoglou C, Sensebe L: Bone regeneration: the stem/ progenitor cells point of view. J Cell Mol Med 2010, 14(1-2):103-115.

5. Urist MR: Bone: formation by autoinduction. Science 1965, 150(698):893-899.

6. Lavery K, Swain P, Falb D, Alaoui-Ismaili MH: BMP-2/4 and BMP-6/7 differentially utilize cell surface receptors to induce osteoblastic differentiation of human bone marrow-derived mesenchymal stem cells. J Biol Chem 2008, 283(30):20948-20958.

7. Deschaseaux F, Sensebe L, Heymann D: Mechanisms of bone repair and regeneration. Trends Mol Med 2009, 15(9):417-429.

8. Fujita A, Sato JR, Rodrigues Lde O, Ferreira CE, Sogayar MC: Evaluating different methods of microarray data normalization. BMC Bioinformatics 2006, 7:469.

9. Fujita A, Sato JR, Ferreira CE, Sogayar MC: GEDI: a user-friendly toolbox for analysis of large-scale gene expression data. BMC Bioinformatics 2007, 8:457

10. Vandesompele J, De Preter K, Pattyn F, Poppe B, Van Roy N, De Paepe A, Speleman F: Accurate normalization of real-time quantitative RT-PCR data by geometric averaging of multiple internal control genes. Genome Biol 2002, 3(7), RESEARCH0034.

11. Rasmussen R: Quantification on the LightCycler. Rapid Cycle Real Time PCR. In Methods and Applications. Edited by: Meuer, S, Wittwer, C and Nakagawara, K. Spring Press, Heidelberg; 2001:21-34.

12. Jensen $L$, Kuhn M, Stark M, Chaffron S, Creevey C, Muller J, Doerks T, Julien P, Roth A, Simonovic M, et al: STRING 8-a global view on proteins and their functional interactions in 630 organisms. Nucleic Acids Res 2009, 37(Database issue):D412-416.

13. Balint $E$, Lapointe D, Drissi H, van der Meijden C, Young DW, van Wijnen AJ, Stein JL, Stein GS, Lian JB: Phenotype discovery by gene expression profiling: mapping of biological processes linked to BMP-2-mediated osteoblast differentiation. J Cell Biochem 2003, 89(2):401-426.
14. Hassan MQ, Tare RS, Lee SH, Mandeville M, Morasso Ml, Javed A, van Wijnen AJ, Stein JL, Stein GS, Lian JB: BMP2 commitment to the osteogenic lineage involves activation of Runx2 by DLX3 and a homeodomain transcriptional network. J Biol Chem 2006, 281(52):40515-40526.

15. Ryoo HM, Lee MH, Kim YJ: Critical molecular switches involved in BMP-2induced osteogenic differentiation of mesenchymal cells. Gene 2006, 366(1):51-57.

16. Gu K, Zhang L, Jin T, Rutherford RB: Identification of potential modifiers of Runx2/Cbfa1 activity in $\mathrm{C} 2 \mathrm{C} 12$ cells in response to bone morphogenetic protein-7. Cells Tissues Organs 2004, 176(1-3):28-40.

17. Mundlos S, Otto F, Mundlos C, Mulliken JB, Aylsworth AS, Albright $S$, Lindhout D, Cole WG, Henn W, Knoll JH, et al: Mutations involving the transcription factor CBFA1 cause cleidocranial dysplasia. Cell 1997, 89(5):773-779.

18. Yang $S$, Wei $D$, Wang D, Phimphilai $M$, Krebsbach PH, Franceschi RT: In vitro and in vivo synergistic interactions between the Runx2/Cbfa1 transcription factor and bone morphogenetic protein-2 in stimulating osteoblast differentiation. J Bone Miner Res 2003, 18(4):705-715.

19. Xiao G, Gopalakrishnan R, Jiang D, Reith E, Benson MD, Franceschi RT: Bone morphogenetic proteins, extracellular matrix, and mitogen-activated protein kinase signaling pathways are required for osteoblast-specific gene expression and differentiation in MC3T3-E1 cells. J Bone Miner Res 2002, 17(1):101-110.

20. Katagiri T, Yamaguchi A, Komaki M, Abe E, Takahashi N, Ikeda T, Rosen V, Wozney JM, Fujisawa-Sehara A, Suda T: Bone morphogenetic protein-2 converts the differentiation pathway of $\mathrm{C} 2 \mathrm{C} 12$ myoblasts into the osteoblast lineage. J Cell Biol 1994, 127(6 Pt 1):1755-1766.

21. Locklin RM, Riggs BL, Hicok KC, Horton HF, Byrne MC, Khosla S: Assessment of gene regulation by bone morphogenetic protein 2 in human marrow stromal cells using gene array technology. I Bone Miner Res 2001, 16(12):2192-2204.

22. Hollnagel A, Oehlmann $V$, Heymer J, Ruther $U$, Nordheim A: Id genes are direct targets of bone morphogenetic protein induction in embryonic stem cells. J Biol Chem 1999, 274(28):19838-19845.

23. Lopez-Rovira T, Chalaux E, Massague J, Rosa JL, Ventura F: Direct binding of Smad1 and Smad4 to two distinct motifs mediates bone morphogenetic protein-specific transcriptional activation of Id1 gene. $J$ Biol Chem 2002, 277(5):3176-3185

24. Kokabu S, Ohte S, Sasanuma H, Shin M, Yoneyama K, Murata E, Kanomata K, Nojima J, Ono Y, Yoda T, et al: Suppression of BMP-Smad signaling axisinduced osteoblastic differentiation by small C-terminal domain phosphatase 1, a Smad phosphatase. Mol Endocrinol 2011, 25(3):474-481.

25. Kraus $\mathrm{P}$, Lufkin T: Dlx homeobox gene control of mammalian limb and craniofacial development. Am J Med Genet A 2006, 140(13):1366-1374.

26. Lee MH, Kim YJ, Kim HJ, Park HD, Kang AR, Kyung HM, Sung JH, Wozney JM, Kim HJ, Ryoo HM: BMP-2-induced Runx2 expression is mediated by Dlx5, and TGF-beta 1 opposes the BMP-2-induced osteoblast differentiation by suppression of Dlx5 expression. J Biol Chem 2003, 278(36):34387-34394.

27. Nakashima K, Zhou X, Kunkel G, Zhang Z, Deng JM, Behringer RR, de Crombrugghe $B$ : The novel zinc finger-containing transcription factor osterix is required for osteoblast differentiation and bone formation. Cell 2002, 108(1):17-29.

28. Lee MH, Kwon TG, Park HS, Wozney JM, Ryoo HM: BMP-2-induced Osterix expression is mediated by Dlx 5 but is independent of Runx2. Biochem Biophys Res Commun 2003, 309(3):689-694.

29. Celil AB, Hollinger JO, Campbell PG: Osx transcriptional regulation is mediated by additional pathways to BMP2/Smad signaling. I Cell Biochem 2005, 95(3):518-528.

30. Bois PR, Grosveld GC: FKHR (FOXO1a) is required for myotube fusion of primary mouse myoblasts. Embo J 2003, 22(5):1147-1157.

31. Siqueira MF, Flowers S, Bhattacharya R, Faibish D, Behl Y, Kotton DN, Gerstenfeld L, Moran E, Graves DT: FOXO1 modulates osteoblast differentiation. Bone 2011, 48(5):1043-1051.

32. Osyczka AM, Diefenderfer DL, Bhargave G, Leboy PS: Different effects of BMP-2 on marrow stromal cells from human and rat bone. Cells Tissues Organs 2004, 176(1-3):109-119.

33. Yueh $Y G$, Gardner DP, Kappen C: Evidence for regulation of cartilage differentiation by the homeobox gene Hoxc-8. Proc Natl Acad Sci USA 1998, 95(17):9956-9961. 
34. Kang M, Bok J, Deocaris CC, Park HW, Kim MH: Hoxc8 represses BMPinduced expression of Smad6. Mol Cells 2010, 29(1):29-33.

35. Lin EA, Kong L, Bai XH, Luan Y, Liu CJ: miR-199a, a bone morphogenic protein 2-responsive MicroRNA, regulates chondrogenesis via direct targeting to Smad1. J Biol Chem 2009, 284(17):11326-11335.

36. Nakanishi G, Kim YS, Nakajima T, Jetten AM: Regulatory role for Kruppellike zinc-finger protein Gli-similar 1 (Glis1) in PMA-treated and psoriatic epidermis. J Invest Dermatol 2006, 126(1):49-60.

37. Beak JY, Kang HS, Kim YS, Jetten AM: Kruppel-like zinc finger protein Glis3 promotes osteoblast differentiation by regulating FGF18 expression. $J$ Bone Miner Res 2007, 22(8):1234-1244.

38. Diekwisch TG, Marches F, Williams A, Luan X: Cloning, gene expression, and characterization of $\mathrm{CP} 27$, a novel gene in mouse embryogenesis. Gene 1999, 235(1-2):19-30.

39. Diekwisch TG, Luan $\mathrm{X}$, McIntosh JE: CP27 localization in the dental lamina basement membrane and in the stellate reticulum of developing teeth. $J$ Histochem Cytochem 2002, 50(4):583-586.

40. Miyazono K: Signal transduction by bone morphogenetic protein receptors: functional roles of Smad proteins. Bone 1999, 25(1):91-93.

41. Zhong N, Gersch RP, Hadjiargyrou M: Wnt signaling activation during bone regeneration and the role of Dishevelled in chondrocyte proliferation and differentiation. Bone 2006, 39(1):5-16.

42. Day TF, Guo X, Garrett-Beal L, Yang Y: Wnt/beta-catenin signaling in mesenchymal progenitors controls osteoblast and chondrocyte differentiation during vertebrate skeletogenesis. Dev Cell 2005, 8(5):739-750.

43. Glass DA, Bialek P, Ahn JD, Starbuck M, Patel MS, Clevers H, Taketo MM, Long F, McMahon AP, Lang RA, et al: Canonical Wnt signaling in differentiated osteoblasts controls osteoclast differentiation. Dev Cell 2005, 8(5):751-764

44. Billiard J, Moran RA, Whitley MZ, Chatterjee-Kishore M, Gillis K, Brown EL, Komm BS, Bodine PV: Transcriptional profiling of human osteoblast differentiation. J Cell Biochem 2003, 89(2):389-400.

45. Kokubu C, Heinzmann U, Kokubu T, Sakai N, Kubota T, Kawai M, Wahl MB, Galceran J, Grosschedl R, Ozono K, et al: Skeletal defects in ringelschwanz mutant mice reveal that Lrp6 is required for proper somitogenesis and osteogenesis. Development 2004, 131(21):5469-5480.

46. Wharton KA Jr: Runnin' with the Dvl: proteins that associate with Dsh/Dvl and their significance to Wnt signal transduction. Dev Biol 2003, 253(1):1-17.

47. Mbalaviele G, Sheikh S, Stains JP, Salazar VS, Cheng SL, Chen D, Civitelli R: Beta-catenin and BMP-2 synergize to promote osteoblast differentiation and new bone formation. J Cell Biochem 2005, 94(2):403-418.

48. Gaur T, Lengner CJ, Hovhannisyan H, Bhat RA, Bodine PV, Komm BS, Javed A, van Wijnen AJ, Stein JL, Stein GS, et al: Canonical WNT signaling promotes osteogenesis by directly stimulating Runx2 gene expression. J Biol Chem 2005, 280(39):33132-33140.

49. Moustakas A, Heldin CH: Ecsit-ement on the crossroads of Toll and BMP signal transduction. Genes Dev 2003, 17(23):2855-2859.

50. Xiao C, Shim JH, Kluppel M, Zhang SS, Dong C, Flavell RA, Fu XY, Wrana JL, Hogan BL, Ghosh S: Ecsit is required for Bmp signaling and mesoderm formation during mouse embryogenesis. Genes Dev 2003, 17(23):2933-2949.

51. Newton AC: Regulation of protein kinase C. Curr Opin Cell Biol 1997, 9(2):161-167.

52. Tu X, Joeng KS, Nakayama KI, Nakayama K, Rajagopal J, Carroll TJ, McMahon AP, Long F: Noncanonical Wnt signaling through G proteinlinked PKCdelta activation promotes bone formation. Dev Cell 2007, 12(1):113-127.

53. Saharinen J, Hyytiainen M, Taipale J, Keski-Oja J: Latent transforming growth factor-beta binding proteins (LTBPs) - structural extracellular matrix proteins for targeting TGF-beta action. Cytokine Growth Factor Rev 1999, 10(2):99-117.

54. Janssens $K$, ten Dijke $P$, Janssens $S$, Van Hul W: Transforming growth factor-beta1 to the bone. Endocr Rev 2005, 26(6):743-774.

55. Hopwood B, Tsykin A, Findlay DM, Fazzalari NL: Microarray gene expression profiling of osteoarthritic bone suggests altered bone remodelling, WNT and transforming growth factor-beta/bone morphogenic protein signalling. Arthritis Res Ther 2007, 9(5):R100.

56. Uzawa K, Grzesik WJ, Nishiura T, Kuznetsov SA, Robey PG, Brenner DA, Yamauchi M: Differential expression of human lysyl hydroxylase genes, lysine hydroxylation, and cross-linking of type I collagen during osteoblastic differentiation in vitro. J Bone Miner Res 1999,

14(8):1272-1280

57. Ge G, Fernandez CA, Moses MA, Greenspan DS: Bone morphogenetic protein 1 processes prolactin to a $17-\mathrm{kDa}$ antiangiogenic factor. Proc Natl Acad Sci USA 2007, 104(24):10010-10015.

58. Tsuji K, Bandyopadhyay A, Harfe BD, Cox K, Kakar S, Gerstenfeld L, Einhorn T, Tabin CJ, Rosen V: BMP2 activity, although dispensable for bone formation, is required for the initiation of fracture healing. Nat Genet 2006, 38(12):1424-1429.

59. Hadfield KD, Farrington Rock C, Inkson CA, Dallas SL, Sudre L, Wallis GA, Boot-Handford RP, Canfield AE: HTRA1 inhibits mineral deposition by osteoblasts: Requirement for the protease and PDZ domains. J Biol Chem 2007.

60. Shibata Y, Tsukazaki T, Hirata K, Xin C, Yamaguchi A: Role of a new member of IGFBP superfamily, IGFBP-rP10, in proliferation and differentiation of osteoblastic cells. Biochem Biophys Res Commun 2004, 325(4):1194-1200.

61. Mandal CC, Drissi H, Choudhury GG, Ghosh-Choudhury N: Integration of phosphatidylinositol 3-kinase, Akt kinase, and Smad signaling pathway in BMP-2-induced osterix expression. Calcif Tissue Int 2010, 87(6):533-540.

62. Bain G, Muller T, Wang X, Papkoff J: Activated beta-catenin induces osteoblast differentiation of $\mathrm{C} 3 \mathrm{H} 10 \mathrm{~T} 1 / 2$ cells and participates in BMP2 mediated signal transduction. Biochem Biophys Res Commun 2003, 301(1):84-91.

63. Dimitriou R, Tsiridis E, Giannoudis PV: Current concepts of molecular aspects of bone healing. Injury 2005, 36(12):1392-1404.

64. Rawadi G, Vayssiere B, Dunn F, Baron R, Roman-Roman S: BMP-2 controls alkaline phosphatase expression and osteoblast mineralization by a Wnt autocrine loop. J Bone Miner Res 2003, 18(10):1842-1853.

doi:10.1186/1756-0500-4-370

Cite this article as: Bustos-Valenzuela et al:: Unveiling novel genes upregulated by both rhBMP2 and rhBMP7 during early osteoblastic transdifferentiation of $\mathrm{C} 2 \mathrm{C} 12$ cells. BMC Research Notes 2011 4:370.

\section{Submit your next manuscript to BioMed Central and take full advantage of:}

- Convenient online submission

- Thorough peer review

- No space constraints or color figure charges

- Immediate publication on acceptance

- Inclusion in PubMed, CAS, Scopus and Google Scholar

- Research which is freely available for redistribution

Submit your manuscript at www.biomedcentral.com/submit
C Biomed Central 